\title{
Demythifying the "Dark Side" of Social Capital: A Comparative Bayesian Analysis of White, Black, Latino, and Asian American Voting Behavior
}

\author{
Baodong Liu
}

Previous studies have suggested that Americans who regularly attend church develop important civic skills which facilitate their participation in politics (e.g., see Verba et al. 1995). Churches were also heralded as important repositories of social capital, particularly for disadvantaged minority groups who have fewer opportunities to develop civic skills (Putnam 2000). Moreover, social capital theorists have argued that homogenous congregations foster the development of bonding (in-group) rather than bridging (out-group) social capital. One important fact, which has not been examined closely in the voting literature, is that American churches are still highly segregated by race/ethnicity according to a recent Gallup Poll (2004). Also unclear in the literature is the differential impact of bonding versus bridging social capital on political participation. Scholarship by Putnam (2000) and Gutmann (1998) suggests that heterogeneity within associational memberships is healthier for democratic citizenship than those with more homogenous memberships. This paper evaluates this claim and investigates whether or not bonding social capital fosters or discourages political participation for both white-majority voters and minorities. Using Bayesian statistical methods, this study, for the first time, conducted a national, cross-racial analysis of whites, Blacks, Latinos, and Asian Americans based on data from the General Social Survey (2002), National Election Studies (2000), and the Pilot National Asian American Political Survey (2001). The finding suggests that church attendance is significant and positively associated with voting participation among racial/ethnic groups that attend churches with mostly homogenous memberships. Contrary to the negative implications purported to stem from the "dark side" of social capital, the results of this research show that bonding social capital positively influences participation in politics. These findings lead to important implications for understanding the mobilization of immigrant communities, a group that political parties rarely attempt to mobilize (Kim 2007; Wong 2006).

During the middle of the Democratic primary season in March of 2008, presidential candidate Barack Obama’s “preacher problem” exploded into the national political landscape. Images of an "angry black man" spewing "anti-American" rhetoric were looped continuously in the media market for American voter consumption. Controversial sound bytes pulled from the Reverend Jeremiah Wright's sermons prompted many Americans to pause and consider what Obama's twenty-year membership at a historically black church in the South Side of Chicago might reveal about his identity and his politics. What was initially considered a potential "campaign killer" did not ultimately cost Obama the election. On Election Day, he won 365 electoral

The author would like to sincerely thank the editor of ARP and the reviewers of this article for very helpful comments and suggestions that greatly improved the quality of the paper.

BAODONG LIU is associate professor of political science at the University of Utah.

The American Review of Politics, Vol. 32, Spring, 2011: 31-55

(C)2011 The American Review of Politics 
votes, more than doubling Senator McCain's 173 votes, making Barack Obama the first African American President of the United States.

The impetus for this study emerges from some of the negative reactions to Obama's membership in an overtly color-conscious congregation. Obama's church affiliation did not cost him the election, but the early controversy surrounding his membership in a black liberation theology teaching church raises an important issue for scholars of political behavior. Of particular interest is the relationship between one's church involvement and his/her political participation. Political science research suggests "bonding social capital” (in-group solidarity), which typically develops in homogenous settings, has the potential for producing negative and illiberal effects on democracy (Gutmann 1998; Putnam 2000). Leaders and organizations that mobilize their constituents along racial/ethnic lines have undergone severe criticism by scholars contending that homogenous voluntary organizations threaten "America's national identity" and leads to "racial balkanization" (Huntington 2004; Schlesinger 1993). In light of these criticisms and the recent controversy over Obama's church membership, this research asks, "Does membership in a racially homogenous church increase or decrease participation in the American political system?"

To answer this question, an integrated approach is used in this research, which situates the research question in the context of American elections and voting. In an attempt to demythify the "dark side" of social capital, the article evaluates previous claims and investigates whether or not bonding social capital fosters or discourages political participation for both whitemajority voters and minorities. Using Bayesian statistical methods, this study, for the first time, conducted a national, cross-racial analysis of whites, Blacks, Latinos, and Asian Americans based on data from the General Social Survey (2002), National Election Studies (2000), and the Pilot National Asian American Political Survey (2001). Contrary to the negative implications purported to stem from the "dark side" of social capital, this study shows that bonding social capital positively influences electoral participation. These findings presented in this paper, thus, demands a new theory that is generalizable to all four major racial/ethnic groups, and the results of this comparative analysis of four racial groups, in particular, have especially important implications for understanding the mobilization of immigrant based communities, a group that political parties rarely attempt to mobilize (Kim 2007; Wong 2006).

\section{Political Participation and Social Capital: A Racial Dimension}

Scholars of political behavior have spent a great deal of time identifying factors that either foster or diminish prospects for political participation. 
In their seminal work on electoral and non-electoral participation, Sidney Verba and Norman Nie (1972) established the classic socioeconomic status (SES) model of participation. Their findings were among the first to show that individuals with higher levels of education, occupation, and income are more likely to participate politically than those with lower levels of SES. In terms of generalizability, the SES model serves as a particularly strong predictor of political participation among whites, but is less consistent in predicting the political behavior of racial/ethnic minority groups such as African Americans, Latinos, and Asian Americans. For instance, racial group consciousness, not SES, is the most consistent predictor of participation among African Americans (Dawson 1994; Tate 1993; Verba and Nie 1972). Based on studies of Latino political behavior, scholars find that education, rather than income or SES overall, is the strongest predictor of political activity (Pantoja et al. 2001). Also, the SES model is problematic in predicting Asian American political behavior. As a group with relatively higher median household incomes, the SES model would predict higher rates of participation among this group. Yet, previous studies show that Asian Americans participate at rates lower than all other major racial and ethnic groups (Cho 1999; Lien 2001; Nakanishi 1991).

But individual resources are not the only source of increasing civic engagement. Spanning back to Tocqueville's (1835) early observations of American democracy, it is well known that participation in associational life cultivates interest in political affairs and provides opportunities for recruitment into political activities. Similarly, institutions such as political parties have been shown to engage and recruit individuals into electoral activity (Campbell et al. 1960; Verba and Nie 1972). However, not all groups are equally targeted by party recruiters. For instance, newer immigrant communities, such as Asian Americans, are rarely mobilized by either of the two major parties (Kim 2007; Wong 2006). Janelle Wong's (2006) research clearly demonstrates how community organizations fill this void by serving as an institutional bridge between these communities and the larger American political system. Although community organizations do not serve as replacements for political parties, particularly in the realm of generating mass mobilization, she argues that these institutions have great potential to foster civic skills, which ultimately increase the capacity for individuals to engage in political life. Furthermore, based on the study of Wong et al. (2005), membership in an ethnic organization is not necessarily associated with voting. Wong et al's main finding is that membership in an ethnic organization may actually be associated with non-voting political activities, such as signing a petition, contacting an elected official and working with others to solve a community problem (also see Uslaner and Conley 2003). 
Verba et al. (1995) specifically point to church involvement as one way to decrease the political participation gap. This is particularly relevant for members of disadvantaged minority groups and the working class, since they typically have fewer opportunities to develop civic skills in the workplace. Within the environs of the church, there are ample opportunities for developing civic skills by giving speeches, organizing and facilitating meetings, mediating disagreements, and holding leadership and administrative responsibility positions. Churches are also heralded as important repositories of social capital. Social capital is the connection between and among social networks developed through face to face contact that foster norms of reciprocity and trustworthiness. Putnam (2000) identifies two types of social capital: bonding and bridging capital. While bonding capital refers to the interpersonal solidarity that typically develops among small groups and local communities over extended periods of time, bridging capital focuses on relationships linking heterogeneous groups together (Putnam 2000; Wuthnow 2002).

In fostering a liberal participatory democracy, many scholars herald bridging capital as superior to bonding capital because it fosters out-group reciprocity, has greater potential for solving collective action problems, and improves the quality of public discourse and deliberation that is healthier for democratic citizenship (Gutmann 1998; Putnam 2000). In contrast, bonding capital has been described as the "dark side" of social capital and has the potential to be oppressive, exacerbate segregation, and produce illiberal effects (Putnam 2000). Given that many Americans spend more time in churches than any other type of voluntary organization, church involvement appears to have great potential for fostering "bridging social capital" rather than "bonding social capital" (Beyerlein and Hipp 2006).

Yet upon closer examination of the racial/ethnic composition of congregations, American churches are more likely to foster bonding rather than bridging capital. According to the National Congregations Survey, nine out of every ten American church congregations are racially homogenous, with at least ninety percent of the congregation representing just one racial group (Chaves 1999). In a separate study, the Multiracial Congregations Project shows that only eight percent of Christian religious communities are multiracial, where no one racial/ethnic group constitutes over eighty percent of the congregation (Emerson 2000). In a more recent survey of racial diversity in American congregations, a 2004 Gallup Poll finds a similar trend. ${ }^{1}$ Sixtyfour percent of whites attend mostly or all white congregations and 56 percent of blacks belong to mostly or all black congregations. In contrast, only half of Latinos attend churches that are mostly or all Latino. Thus, Latinos are distinct in their propensity to attend mostly heterogeneous churches where fellow members are less likely to share their same ethnic background. 
Although there is no national comparative data available for Asian Americans, research in ethnic studies firmly establish that religion remains centrally important in the community (Ecklund and Park 2005) and that the ethnic church is one of few available institutions for gathering with coethnics (Hurh and Kim 1990). Particularly among individuals hailing from immigrant based communities, the ethnic church provides meaning, belonging, and comfort for those uprooted from the communal and associational bonds they left in their home countries (Hurh and Kim 1990). Moreover, churches have been found to help first generation Asian immigrants overcome deficits in social status as a result of their immigration to a new country and help the children of immigrants maintain their ethnic identities (Ecklund and Park 2005). ${ }^{2}$

Similar to claims about the oppressive and divisive nature of bonding social capital, racial/ethnic based institutions are also viewed as antithetical to the development of liberal democratic values (Huntington 2004; Schlesinger 1993). Adopting this viewpoint, attendance at racially homogenous church congregations should then decrease one's engagement in the American political system. Yet research on African American churches has consistently shown that church attendance increases the political participation of blacks (Brown and Brown 2003; Calhoun-Brown 1996; Tate 1993), Asian American voting participation increases with church attendance (Lien et al. 2004), and studies of immigrant communities show that ethnic based organizations draw immigrants into the political system to a greater extent than ever before (Wong 2006). To explain the positive effects of ethnic based organizations, Wong (2006) would argue that they are better positioned to generate collective action because they possess cultural, linguistic, and substantive knowledge of their local immigrant populations that non-ethnic based organizations typically lack.

For racial/ethnic minorities, there are additional barriers that might inhibit the accrual of benefits perceived to flow from church membership. Emerson and Smith (2000) contend that there is a greater "cost" of acquiring "meaning, belonging, and security" when one belongs to the minority group within a congregation. Moreover, minorities who remain on the "edge" of a heterogeneous congregation have fewer relational ties to the core of the group and are likelier to leave the congregation altogether (Emerson and Smith 2000; Jeung 2005). The sociology literature also points to the "homophily principle," the theory that similarity cultivates connection and that relationships forged between similar individuals will be more binding (Marsden 1987; McPherson et al. 2001). While the homophily principle explains why so many American churches are racially/ethnically segregated today, the perspective that members on the "edge" endure greater costs suggests 
that it is more difficult for congregational minorities to develop civic skills in racially/ethnically heterogeneous environments.

Taken altogether, we anticipate that opportunities for racial/ethnic minorities to develop civic skills are diminished in settings where they constitute a numerical minority within that congregation. In contrast, in settings where one constitutes a numerical majority, individuals will possess stronger relational ties with other members and bear a lower cost for developing a sense of belonging within the church. Consistent with the principle of homophily, the racial/ethnic homogeneity of the congregation reduces the costs of developing meaningful connections among church members that facilitate greater church involvement. Members who feel more socially connected to other church members will be more likely to take advantage of opportunities to develop the civic skills that translate into greater civic participation down the line.

The continuing prevalence of racially/ethically homogenous church congregations in America provides an excellent opportunity for us to assess whether or not bonding social capital has either positive or negative consequences for political participation. If churches provide ample opportunities to develop civic skills which facilitate their participation in politics, and racial/ethnic based organizations are better equipped to mobilize their members because they possess "insider" knowledge of the community that mainstream organizations typically lack (Tate 1993; Wong 2006), we hypothesize that a homogenous church environment may be a real boon for political participation, particularly for groups that are typically ignored by larger, more established recruiting institutions.

\section{Anticipated Findings}

This paper challenges the assumption that bridging social capital is better for fostering democratic citizenship. It is contended here that bonding social capital developed in racially homogenous church congregations can have a positive mobilizing effect on political participation. The focus of our investigation is on voting behavior across four major racial/ethnic groups: whites, Blacks, Latinos, and Asian Americans. It is hypothesized that groups that attend mostly racially homogenous church congregations will be more likely to vote. Since Latinos are the least likely group to attend a racially homogenous congregation, we expect that church attendance will not encourage Latino participation in voting. In contrast, we expect that church attendance will have a positive and significant effect on the voting behavior of whites, Blacks, and Asian Americans, groups that tend to belong to racially homogenous congregations. 


\section{Data and Methods}

To investigate how social capital either positively or negatively influences voting behavior across racial groups, one must first rely on data that enables cross group comparisons. Unfortunately, as stated earlier, no such data are available to conduct either cross-sectional or longitudinal studies for all major racial groups with the same quantitative measures. The two major national surveys, GSS and NES either did not sample all racial groups, or do not have variables that would allow us to examine all four racial groups simultaneously. In this paper, we use data from three different national surveys: General Social Survey (2002), National Election Studies (2000), and the Pilot National Asian American Political Survey (PNAAPS [2001]). The key dependent variable in the analysis is voting in the 2000 election. The key independent variable of interest is church attendance ( 1 for respondents who attend church, 0 for those who do not). The control variables we include from all three surveys are as follows: age, gender, income, education, activism, political interest, internet use, and trust. In analyzing Asian Americans using the PNAAPS dataset, we added two additional independent variables in the analysis: born in Asia and membership in ethnic organizations.

For our method, we use the Bayesian approach to test the effect of church attendance on voting. We believe the Bayesian approach is superior to other methodological approaches (i.e., using logistic regression for dichotomous dependent variables) for three reasons. First, the Bayesian approach allows all parameters to be estimated in probability terms. Second, because results using the Bayesian approach are based on the posterior distribution of the quantities of interest, it indicates the improvement of the estimation. Third, we can specify the model to make the data (not the priors) more dominant if we are unclear about what we estimate. In doing so, we are able to make the Bayesian approach a maximum likelihood run of the model, and nothing is lost in the hypothesis testing. Thus, we believe the Bayesian approach improves on the drawbacks of the null-hypotheses approach, which often arbitrarily makes decisions based on the p-value at a critical point (normally p must be less than .05).

Moreover, the Bayesian approach is better equipped at analyzing survey data variables, which often suffer from missing data issues in the dependent variable and major independent variables. This is especially important if the survey data have "racial" aspects. For example, minorities are not often sampled, even in national surveys such as the GSS. The key dependent variable, voting, can create a missing data problem especially when we want to compare whites with minorities. If we only rely on the GSS (2002) and we test our hypotheses based on the nine variables we need (see below), then only 45 respondents were classified in the "other races" category (i.e., 
Latinos, Asians, and so on). Furthermore, because only 39 of the 45 respondents answered the question on voting, we are missing important data about the dependent variable. In this case, the traditional "Neyman-Pearson" frequentist approach is virtually useless because of the small- $\mathrm{N}$ and missing data issues.

In the Bayesian model, the dependent variable can be estimated. The missing data problem can be handled through "multiple imputation" (Gill 2004, 333). To illustrate our empirical model, we began with our dependent variable, which is a dichotomous measure indicating whether individuals voted or not. We first derived a probability distribution of the dependent variable with a simple Bernoulli distribution. We then used WinBugs software to write a logit link model. We tested our model based on the uninformative priors (i.e., let the data be more dominant). To be more specific, the priors for the Beta parameters are specified as multivariate normal with two parameters. We then compared this base model with other models that specify our major independent variable, church attendance based on past research findings. In doing so, we evaluated our model improvement through posterior distribution of our quantities of interests for different racial groups.

\section{Results of Descriptive Statistical Analysis}

Before discussing the results of our main hypotheses, we first present the results of descriptive analyses for each of the four racial groups' frequency in church attendance. Table 1 lists the dispersion of the standard church attendance variable used in typical national surveys (NES 2000 and NES 2004). Based on the most recent 2004 data, Asian Americans (32\%) are the group most likely to attend church on a weekly basis, slightly more frequently than African-Americans (29\%). Whites (23\%) and Latinos (21\%) are the least likely groups to attend church services on a weekly basis. Two simple chi-square tests for both NES 2000 and NES 2004 indicate there are statistically significant differences in the frequency of church attendance when comparing all four groups.

Examining religious activities and beliefs associated with church attendance offer another important point of comparison for at least three of the four racial groups. The results in Figures 1 and 2 show the religious activities and belief systems that church involvement fosters. We constructed a religious index based on a composite scale of four variables in the NES which not only measures church attendance, but also prayer frequency, opinions on the Bible, and the overall influence of religion on their lives.

Figure 1 compares Whites with Blacks based on these four composite variables. Based on these data, Blacks are much more religiously active than 
A Comparative Analysis of American Voting Behavior | 39

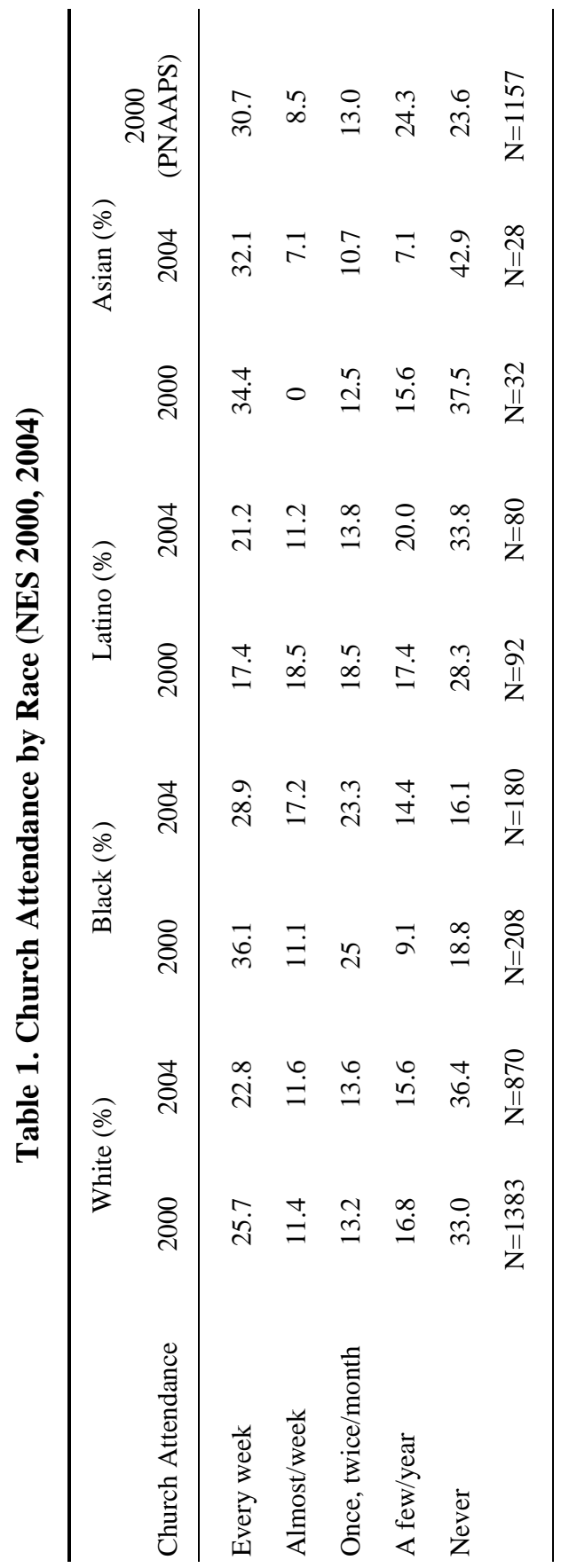


Figure 1. Religious Activities of Whites and Blacks, Compared (NES 2004)

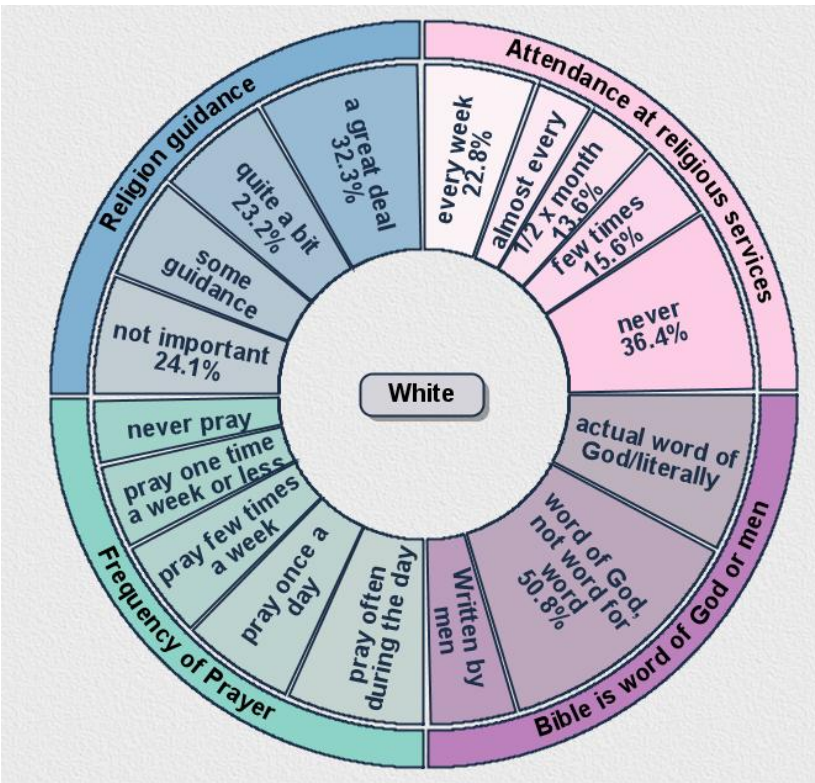

$876 / 1212$

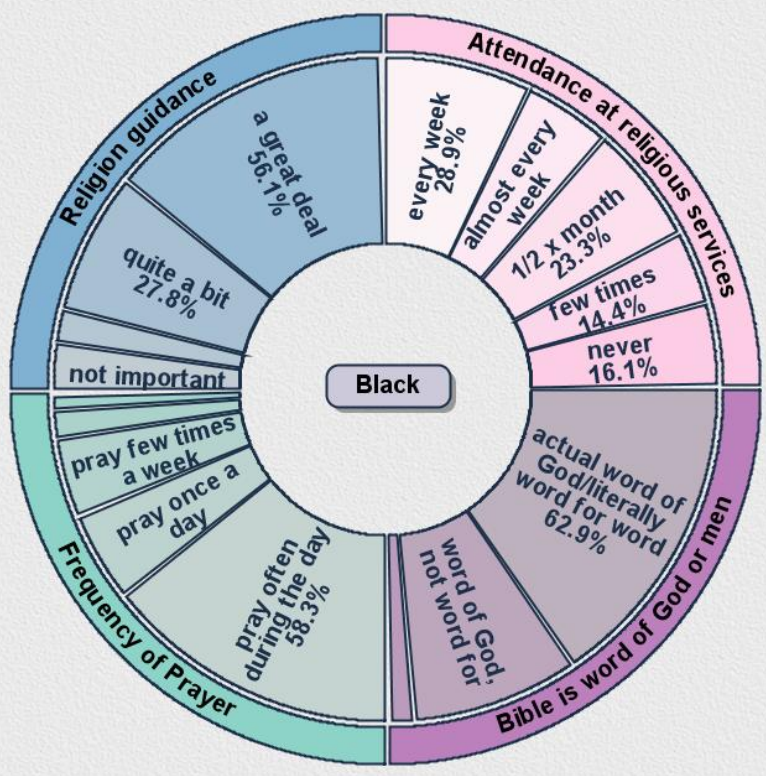


Figure 2. Religious Activities of Whites and Latinos, Compared (NES 2004)
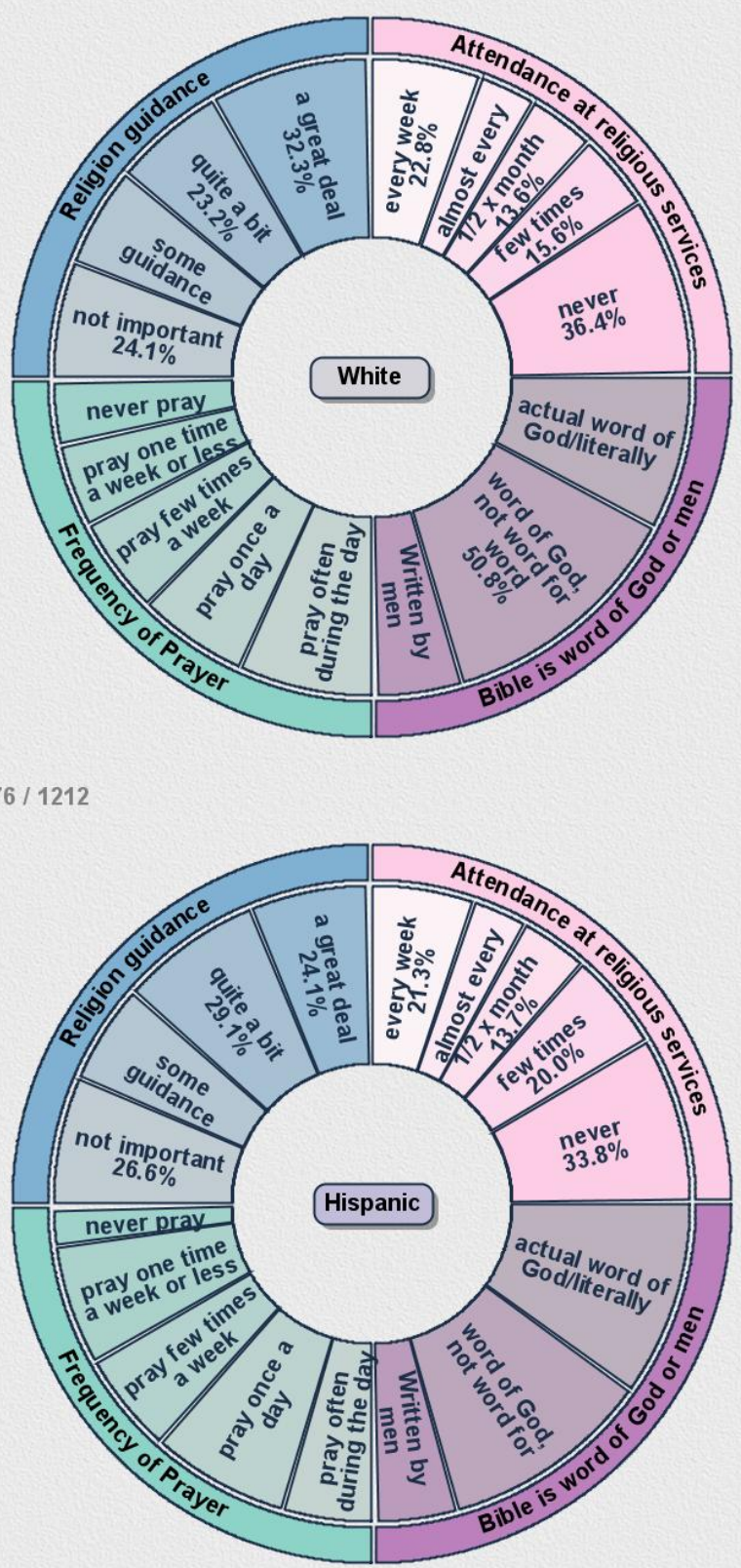
Whites. Blacks are more likely to attend church, believe in the Bible as the Word of God, pray frequently, and rely on religion as the major influence in their lives. The mean for the black racial group's religious index is 9.6 while that for the white group is 10.3. $(\mathrm{t}=-4.3$, significant at .001 level $)$.

Figure 2 compares Whites with Latinos in terms of their religious activity distribution. Overall, Whites and Latinos were engaged in strikingly similar level of religious activities based on their prayer frequency, belief in the Bible, religious influence as well as church attendance. The mean for the Latino group's religious index is 10.1 , which is almost identical to that for the white group at $10.3(\mathrm{t}=-.77$ and obviously statistically insignificant).

In terms of denominations, Table 2 provides a snapshot of each group and their affiliation. Whites (53\%) and Blacks (90\%) are the two likeliest groups to belong to Protestant churches. Latinos are the group least likely to attend Protestant churches (27\%) and the group most likely to be Catholic (53\%). In terms of political interest and activities, Protestants are slightly more likely to vote in the 2000 presidential election (71\%), more interested in following campaigns (38\%), care more about who wins a presidential election (88\%), but less likely to belong to a labor union (15\%) than Catholics.

Considering that Latinos are the group most likely to be Catholic, how do Latino Catholics fare against Catholics in general for these same measures? The results presented in Figure 3 indicate that Latino Catholics (56\%) are less likely to vote in the 2000 presidential election than Catholics in general (66\%). Latino Catholics are also less interested in following campaigns and care less about who wins the presidential election. This initial comparison suggests that at least among Latinos attending Catholic churches, church attendance alone does not have enough of a political mobilizing effect to increase political interest and activities to the level of Catholics in general. It is most likely a factor related to the immigrant experience that inhibits their participation but could also be due to factors yet to be discovered. To find out more, we need to take our analysis to the next level. We now turn to the results of our Bayesian regression analysis to identify which factors are most significant for predicting voting behavior.

\section{Results of Bayesian Regression Analysis}

The results of the four models (for each racial group) are presented in Table 3 with beta posterior parameter estimates and their respective credible intervals at different levels. The key to interpreting the results is to find the credible intervals that do not contain zero, which shows the nonzero effect of the variable. The mean is based on the average value of the simulations for the specific parameter, and its sign reveals the direction of 
A Comparative Analysis of American Voting Behavior | 43

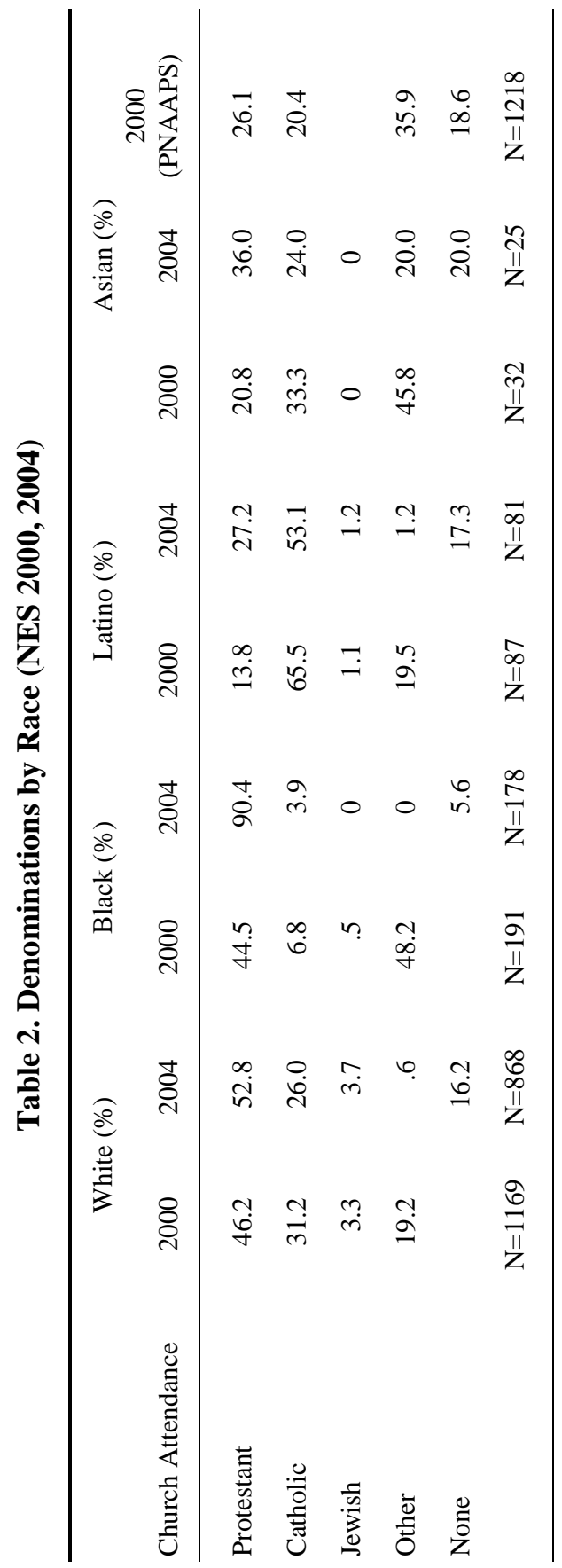


Figure 3. Catholics in General and Latino Catholics, Compared (NES 2004)

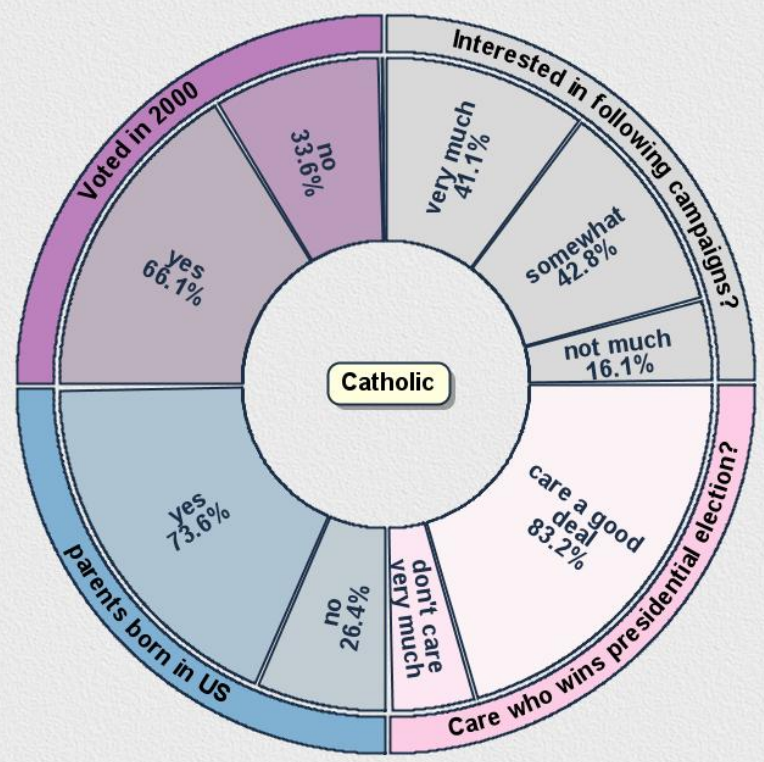

$292 / 1212$

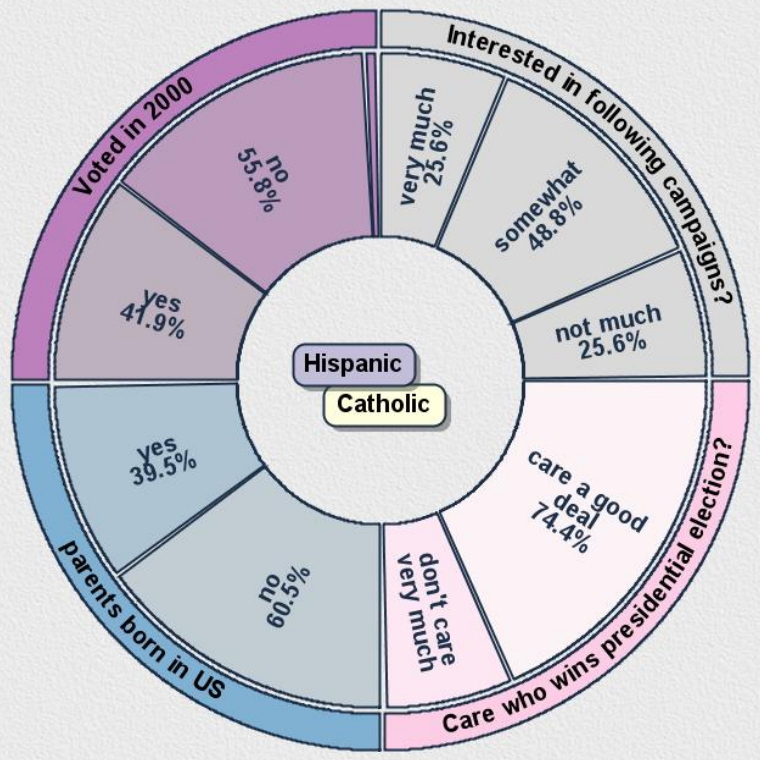


Figure 4. Religious Activities of Protestants and Catholics, Compared (NES 2004)
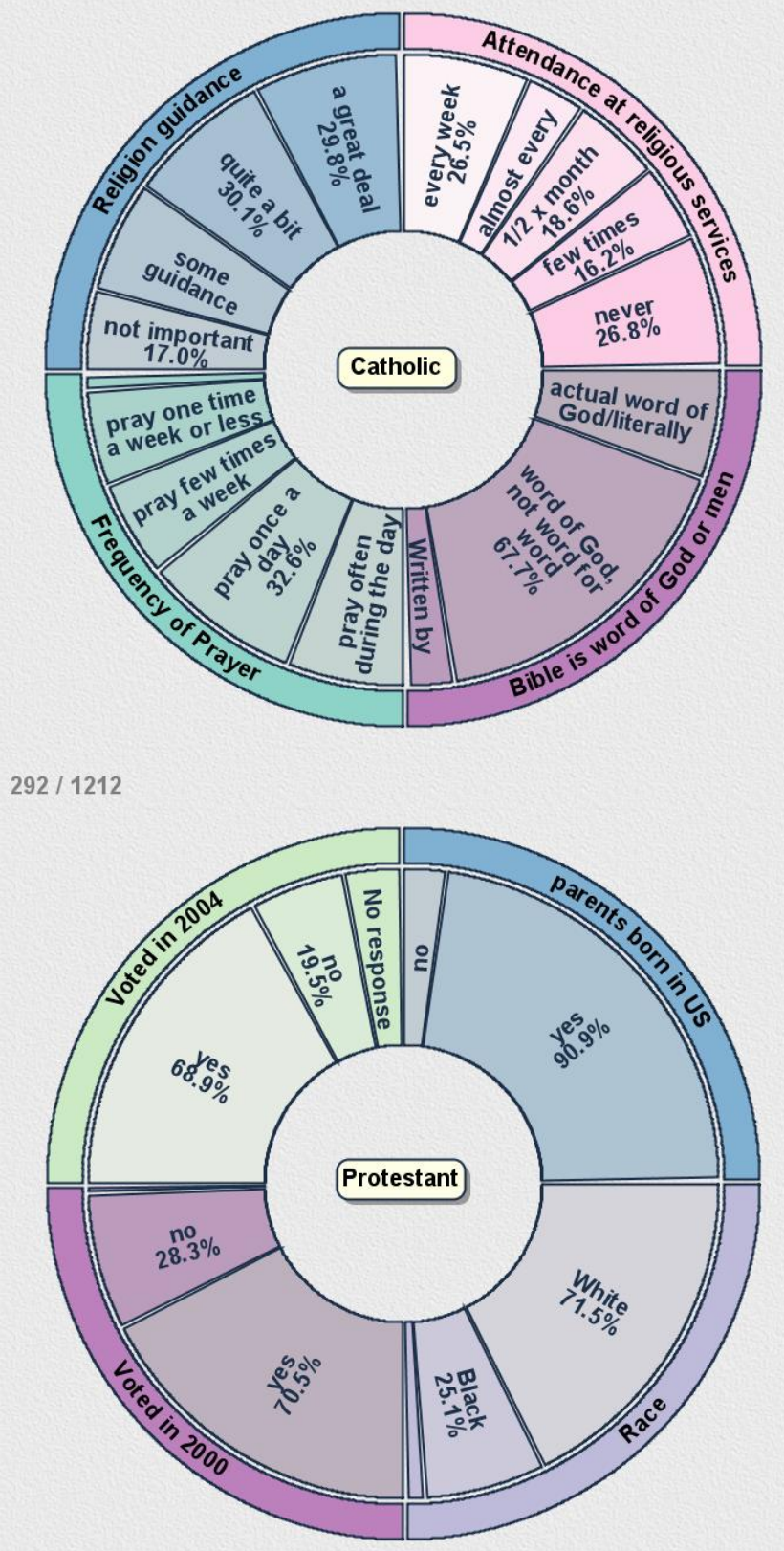


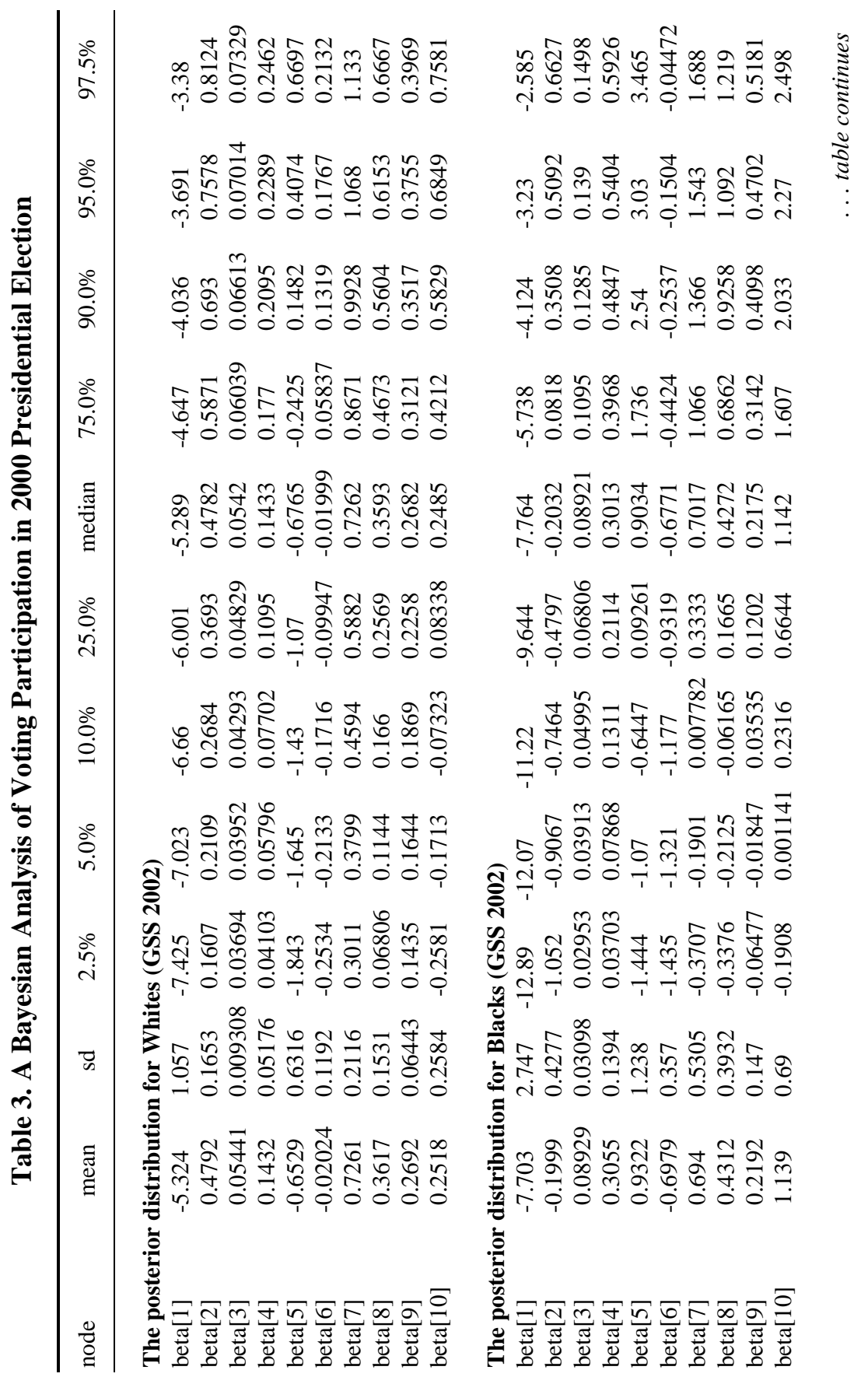




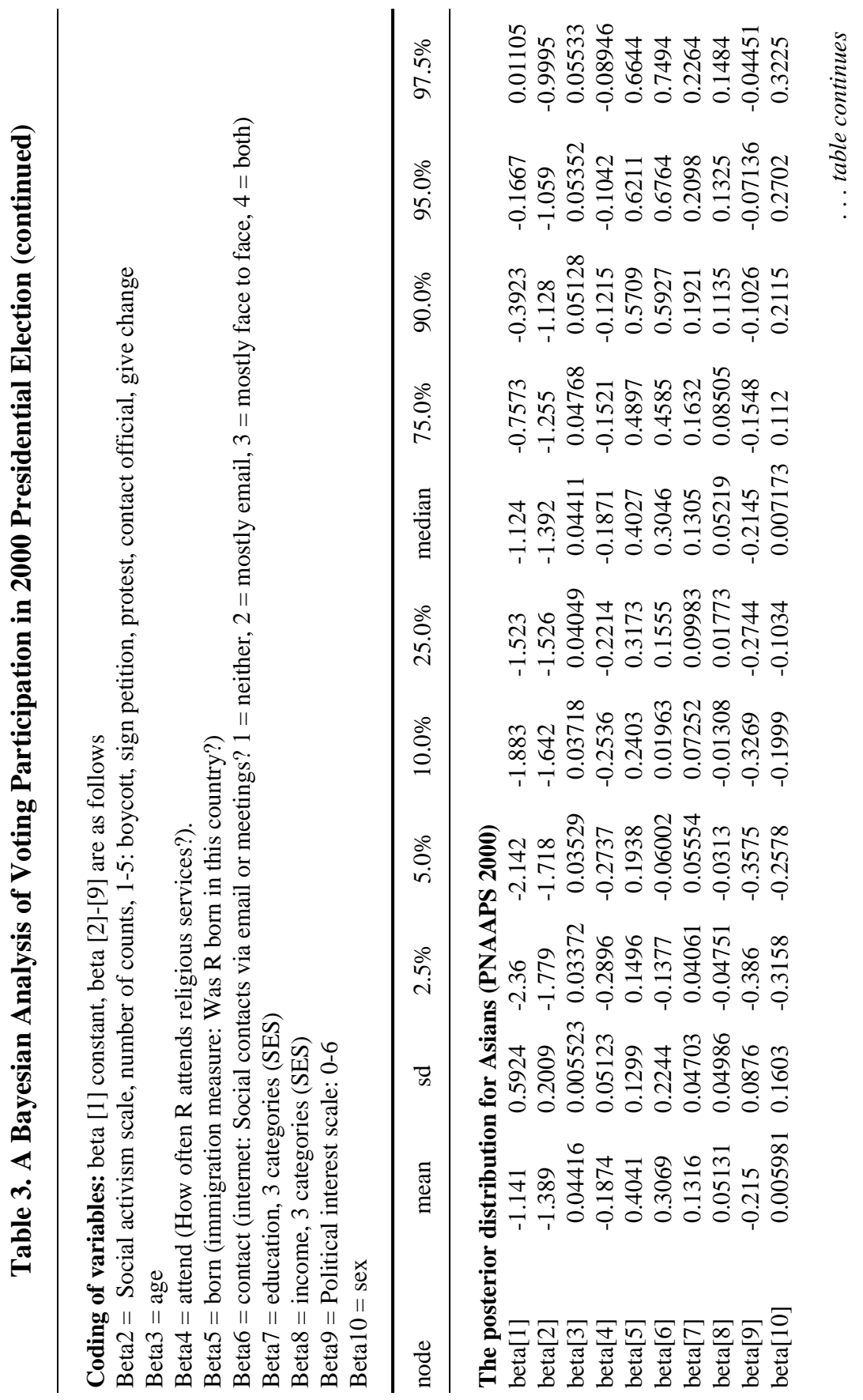



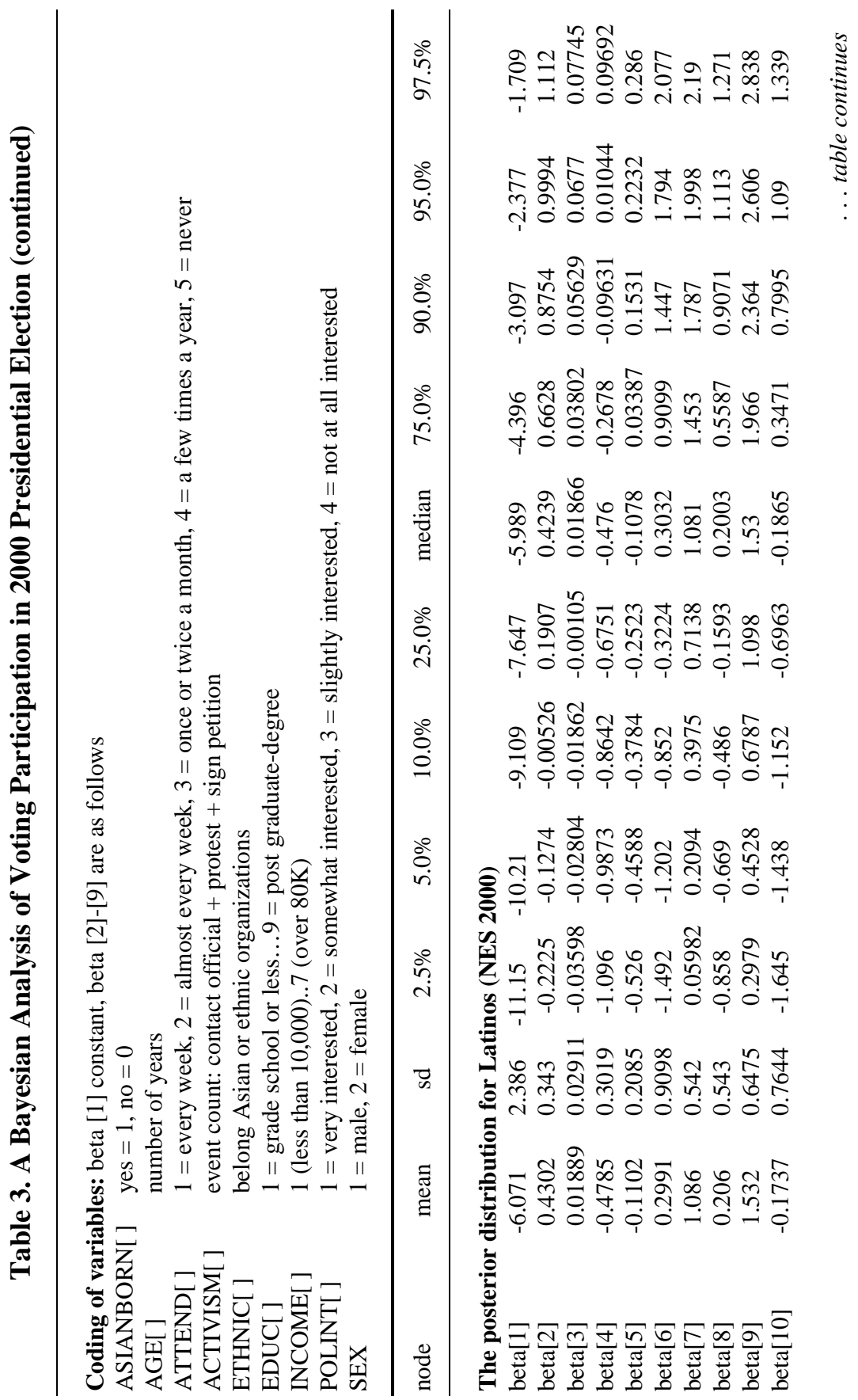
A Comparative Analysis of American Voting Behavior | 49

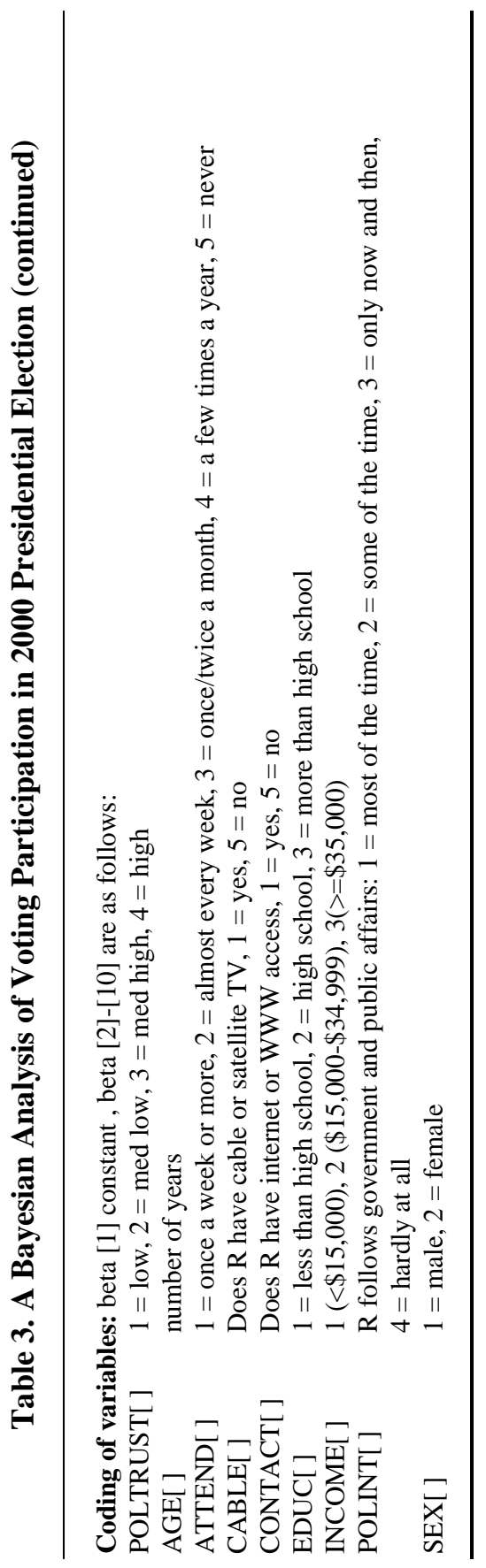


the relationship. To minimize the MC error, we performed at least 10,000 simulations to approximate the posterior distribution for each model.

For Whites, we ran Bayesian analysis with both the GSS and NES data concerning the 2000 presidential election. The results are substantially similar. For Blacks, we ran the basic Bayesian model with the priors dominated by the data. We then tried different prior specifications based on the findings from the GSS and performed a similar model using the NES. The results, of course, were not identical, because GSS and NES are two different surveys with different sets of variables. However, we report the results based on the models that maximized the findings of possible explanations for voting for each specific racial group. For Latinos, we were able to run the NES model based on its reasonable sample size that did allow the same Bayesian operation. ${ }^{3}$ For Asian Americans, we only reported the Bayesian findings from the PNAAPS data, rather than the NES data, because using the Bayesian model would have only 21 cases in the 2000 NES data for Asian Americans $(\mathrm{N}=21){ }^{4}$

To help better organize the findings, we provide a summary report in Table 4. The results of the analysis reveal different outcomes for whites than for nonwhites. In our model, Whites exhibit more positive signs than all other racial groups based on both NES and GSS models. Thus, Whites possess more positive cues to participate in voting than other minority groups. Furthermore, all minority groups had at least one factor that significantly decreased their likelihood of voting. For Asian Americans, those who were born outside the U.S. were less likely to vote than those who were native-born. For African Americans, the access to internet in fact limited them to vote, which suggests that the development of internet technology indeed may play a negative role in social capital accumulation, as implied in Putnam's (2000) original study of the impact of modern technology. But this finding only applied to African Americans. With respect to Latinos, the political interest variable is negative. One possible explanation is that Latinos who pay attention to politics may be more attuned to the difficulty Latinos face insignificantly influencing election outcomes, reducing their propensity to vote. Finally, involvement in Asian ethnic organizations did not play a positive role in enhancing Asian Americans' voting ratio. Although previous research highlighted the mobilizing effect of membership in Asian-American ethnic organizations (Wong 2006) our study finds that church membership is a significant mobilizing force for Asian Americans.

To briefly summarize some of the control variable results, only age emerges as significant for most racial groups; older Whites, African Americans and Asian Americans are more likely to vote than their younger counterparts, even when controlling for the related influences of SES and social capital. Our results reveal no differences between males and females in 
Table 4. Explanations for Voting Participation in the 2000 Presidential Election, Four Racial Groups Compared

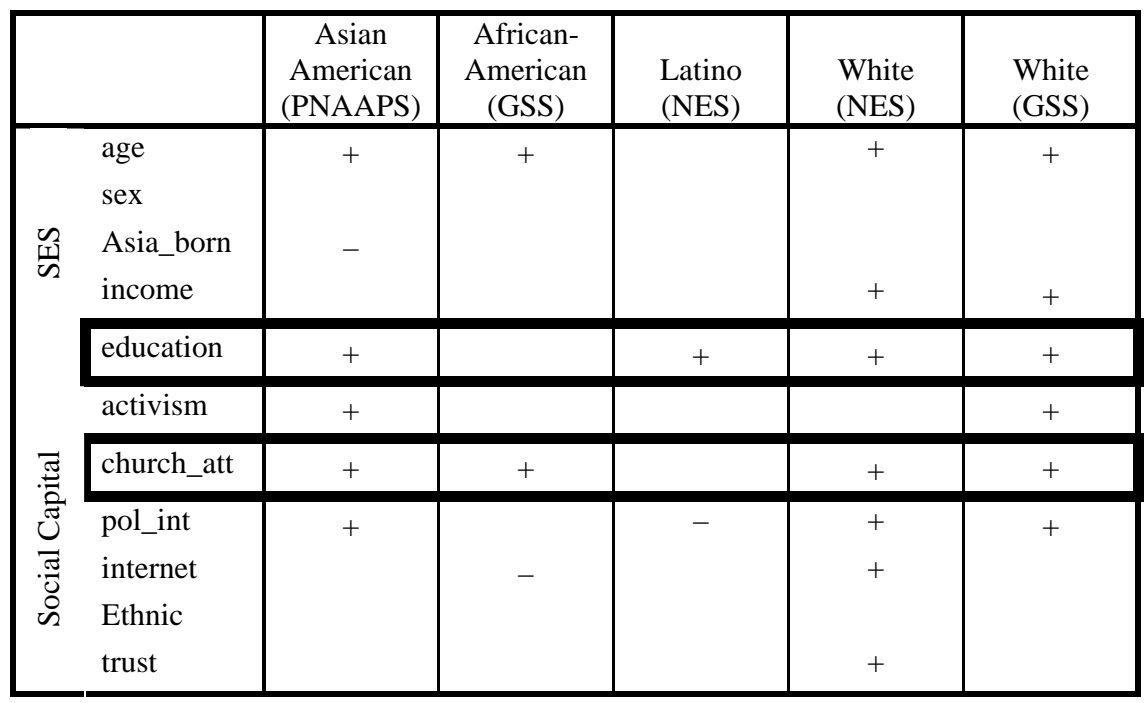

voting patterns. Although traditional participation models predict that SES will increase voting participation of all racial groups, we find that SES fails to significantly influence voting for African Americans (the credible interval includes zero or "no effect" as a possible estimate). Education is a positive factor for all racial groups, except for Blacks. This finding is consistent with previous findings that show SES models are poor predictors of African American participation (Verba and Nie 1972). Finally, for our key variable of interest, for whites, two social capital variables, social activism and church attendance, both enhance voting participation based on the GSS model (the 95\% credible intervals for these variables do not include zero). For African Americans, church attendance is the only social capital variable that significantly increased voting participation. For Asian Americans, church attendance led to increased levels of voting. For Latinos, attending church has no significant effect on voting behavior. These findings confirm our hypothesis that church attendance increases participation among racial groups that attend racially homogenous churches.

\section{Conclusions and Discussion}

To conclude, the most important finding to emerge from this study is the significant and positive effect of church attendance on all racial groups, except Latinos. This finding confirms our hypothesis, suggesting that the 
so-called "dark side" of social capital does not seem to occur in the realm of voting behavior. As the Gallup Poll data indicate, Americans tend to belong to racially homogeneous church congregations. Our results suggest that this homogeneity may play a positive, rather than negative role in mobilizing voters.

In contrast, Latino voting behavior does not seem to obtain a boost from church attendance. Thus, since Latinos are more likely to attend churches that are more racially heterogeneous, which generates bridging capital instead of bonding capital, we believe the racial composition of the church may prove to be a critical factor in how social capital influences voting behavior. Our findings run counter to the belief that bridging capital is always more beneficial to fostering democracy than bonding capital, at least in the realm of voting behavior.

In light of these results, this paper contends that the racial composition of church congregations may influence the type of social capital that develops within churches (bridging versus bonding forms of capital) and reduce the otherwise positive effects of church attendance for participation. Opportunities for racial/ethnic minorities to develop civic skills may be diminished in church settings where they constitute a numerical minority within that congregation. In contrast, in settings where one constitutes a numerical majority, individuals may possess stronger relational ties with other members and bear a lower cost for developing a sense of belonging within the church. Consistent with the principle of homophily, the racial/ ethnic homogeneity of the congregation may reduce the costs of developing meaningful connections among church members that facilitate greater church involvement.

Members who feel more socially connected to other church members may be more likely to take advantage of opportunities to develop the civic skills that translate into greater civic participation down the line. Moreover, if churches provide ample opportunities to develop civic skills which facilitate their participation in politics, and racial/ethnic based organizations are better equipped to mobilize their members because they possess "insider" knowledge of the community that mainstream organizations typically lack (Tate 1993; Wong 2006), it is quite possible that a homogenous church environment may be a real boon for political participation, particularly for groups that are typically ignored by larger, more established recruiting institutions.

Finally, a further note on the limitation of this paper is necessary. First, due to the nature of the national survey concerning white respondents, this paper was not able to address some important research questions. One such question would be whether or not attendance in homogenous vs. heterogeneous and/or multiracial churches matters for Whites. Second, there are a 
large number of non-Judeo-Christian religious adherents among Asian ethnic groups who do not attend "church." In fact, they attend certain temples, dependent upon how "religious languages" are used in the survey questions. Further, some groups, such as Buddhists, may be quite religious, but they do not attend religious services regularly. The most serious problem for the student of race, as far as Asian Americans are concerned, however, is that church attendance (at Christian churches) may vary greatly by national origin-making it fairly difficult to distinguish between the effects of religion and national origin.

\section{NOTES}

${ }^{1}$ Asian Americans were not sampled in the 2004 Gallup Poll on race and religion.

${ }^{2}$ For more research on the growing presence of Asian American church congregations, see Ecklund and Park 2005, 2007; Hurh and Kim 1990; Jeung 2005; Alumkal 2003.

${ }^{3}$ It should be noted that the 2000 NES data do have some internal sampling problems. First, NES has always been a national survey, which has not used an oversample of minorities, especially Latinos and Asians. Second, the survey was conducted in English, thus, it excluded those non-English speakers from the sampling procedure.

${ }^{4}$ The PNAAPS, it should also be noted, was not a national survey. Instead, it was a survey conducted in five metropolitan areas. Thus, the readers of this paper should be cautioned to make limited generalization of the results presented in this study about the national population.

\section{REFERENCES}

Beyerlein, Kraig, and John R. Hipp. 2006. From Pews to Participation: The Effect of Congregation Activity and Context on Bridging Civic Engagement. Social Problems 53(10):97-117.

Brown, R. Khari, and Ronald E. Brown. 2003. Faith and Works: Church-Based Social Capital Resources and African American Political Activism. Social Forces 82(2): 617-641.

Alumkal, Antony W. 2003. Asian American Evangelical Churches: Race, Ethnicity, and Assimilation in the Second Generation. New York: LFB Scholarly Publishing LLC.

Calhoun-Brown, Allison. 1996. African American Churches and Political Mobilization: The Psychological Impact of Organizational Resources. Journal of Politics 58(4): 935-953.

Campbell, Angus, Phillip Converse, Warren Miller, and Donald Stokes. 1960. The American Voter. New York: Wiley.

Chaves, M. 1999. National Congregations Study. Machine-readable file. Tucson: University of Arizona, Department of Sociology.

Cho, Wendy K. Tam. 1999. Naturalization, Socialization, Participation: Immigrants and (Non-)Voting. Journal of Politics 61(4):1140-1155. 
Dawson, M.C. 1994. Behind the Mule: Race and Class in African-American Politics. Princeton, NJ: Princeton University Press.

Ecklund, Elaine Howard, and Jerry Z. Park. 2007. Religious Diversity and Community Volunteerism Among Asian Americans. Journal for the Scientific Study of Religion 46(2):233-244.

Ecklund, Elaine Howard, and Jerry Z. Park. 2005. Journal of Asian American Studies 8(1):1-21.

Emerson, M.O. 2000. Lilly Survey of Attitudes and Friendships. Machine-readable file. Houston, TX: Rice University, Department of Sociology.

Emerson, M.O., and C. Smith. 2000. Divided by Faith: Evangelical Religion and the Problem of Race in America. New York: Oxford University Press.

Gill, Jeffrey. 2004. Introduction to the Special Issue. Political Analysis 12(4):323-337.

Gutmann, Amy. 1998. Freedom of Association. Princeton, NJ: Princeton University Press.

Huntington, Samuel. 2004. Who Are We? The Challenges to America's National Identity. New York: Simon and Schuster Paperbacks.

Hurh, Won Moo, and Kwang Chung Kim. 1990. Religious Participation of Korean Immigrants in the United States. Journal for the Scientific Study of Religion 29(1):19-34.

Jeung, Russell. 2005. Faithful Generations: Race and New Asian American Churches. New Brunswick, NJ: Rutgers University Press.

Kim, Thomas. 2007. The Racial Logic of Politics: Asian Americans and Two-Party Competition. Philadelphia, PA: Temple University Press.

Lien, P., M.M. Conway, and J. Wong. 2004. The politics of Asian Americans diversity and community. New York: Routledge.

Lien, Pei-te. 2001. The Making of Asian America through Political Participation. Philadelphia, PA: Temple University Press.

Marsden PV. 1987. Core discussion networks of Americans. American Sociological Review 52:122-313.

McPherson, Smith-Lovin and Cook. 2001. Birds of a Feather: Homophily in Social Networks. Annual Review of Sociology 27:415-444.

Nakanishi, Don. 1991. The Next Swing Vote? Asian Pacific Americans and California Politics. Pp. 25-54 in Racial and Ethnic Politics in California, eds. Byran O. Jackson and Michael B. Preston. Berkeley, CA: IGS Press.

Pantoja, Adrian D., Ricardo Ramirez, and Gary M. Segura. 2001. Citizens by Choice, Voters by Necessity: Patterns in Political Mobilization by Naturalized Latinos. Political Research Quarterly 54(December):729-750.

Putnam, Robert 2000. Bowling Alone: The Collapse and Revival of American Community. New York: Simon and Schuster.

Schlesinger, Arthur. 1993. The Disuniting of America. New York: Norton.

Tate, K. 1993. From Protest to Politics, the New Black Voters in American Elections. New York: Russell Sage Foundation.

Tate, Katherine. 1991. Black Political Participation in the 1984 and 1988 Presidential Elections. American Political Science Review 85(December):1159-1176.

Tocqueville, Alexis. 2000 [1835]. Democracy in America. Chicago: University of Chicago Press.

Uslaner, Eric M., and Richard S. Conley. 2003. Civic Engagement and Particularized Trust: The Ties that Bind People to their Ethnic Communities. American Politics Research 31(4):331-360.

Verba, Sidney, and Norman Nie. 1972. Participation in America: Political Democracy and Social Equality. New York: Harper and Row. 
Verba, S., K.L. Schlozman, and H.E. Brady. 1995. Voice and Equality: Civic Voluntarism in American Politics. Cambridge, MA: Harvard University Press.

Wong, Janelle. 2006. Democracy's Promise: Immigrants and American Civic Institutions. Ann Arbor: University of Michigan Press.

Wong, Janelle, Pei-te Lien, and M. Margaret Conway. 2005. The Role of Group-Based Resources in the Political Participation of Asian Americans. American Politics Research 33(4) (July): 545-576.

Wuthnow, Robert. 2002. Religious Involvement and Status-Bridging Social Capital. Journal for the Scientific Study of Religion 41(4):669-684. 